\title{
PENGARUH PUPUK KANDANG AYAM DAN PUPUK NPK PELANGI TERHADAP PERTUMBUHAN DAN HASIL TANAMAN TOMAT CHERRY (Solanum lycopersicum L.)
}

\author{
Jesyca Suriana $^{1}$, Hery Sutejo ${ }^{2}$, dan Marisi Napitupulu ${ }^{2}$ \\ ${ }^{1}$ Agroteknologi, Fakultas Pertanian, Universitas 17 Agustus 1945 Samarinda, Indonesia. \\ ${ }^{2}$ Dosen Fakultas Pertanian, Universitas 17 Agustus 1945 Samarinda 75124, Indonesia. \\ E-Mail: jesyca@untag-smd.ac.id
}

\begin{abstract}
ABSTRAK
Pengaruh Pupuk Kandang Ayam dan Pupuk NPK Pelangi Terhadap Pertumbuhan dan Hasil Tanaman Tomat Cherry (Solanum lycopersicum L.). Tujuan penelitian untuk mengetahui pengaruh pupuk kandang ayam dan pupuk NPK Pelangi serta interaksinya terhadap pertumbuhan dan hasil tanaman tomat cherry, dan juga untuk memperoleh dosis pupuk kandang ayam dan pupuk NPK Pelangi yang tepat untuk hasil yang maksimal.

Penelitian dilaksanakan selama 4 bulan, yaitu mulai bulan Maret sampai dengan bulan Juni 2017, terhitung sejak pembibitan hingga pengambilan data terakhir. Tempat Penelitian di Kampung Bentas RT 01, Kecamatan Siluq Ngurai, Kabupaten Kutai Barat, Provinsi Kalimantan Timur.

Penelitian menggunakan analisis faktorial 3 x 3 dalam Rancangan Acak Lengkap (RAL), dengan 5 ulangan. Faktor penelitian terdiri atas 2 faktor. Faktor I adalah Pupuk Kandang Ayam (K), terdiri atas 3 taraf, yaitu : tanpa pupuk kandang ayam atau kontrol $\left(\mathrm{k}_{0}\right)$, dosis pupuk kandang ayam 5 ton/ha setara $180 \mathrm{~g} / \mathrm{polibag}\left(\mathrm{k}_{1}\right)$, dan dosis pupuk kandang ayam 10 ton/ha setara $360 \mathrm{~g} /$ polibag $\left(\mathrm{k}_{2}\right)$. Faktor II adala Pupuk NPK Pelangi (P), terdiri atas 3 taraf, yaitu : tanpa pupuk NPK Pelangi atau kontrol $\left(\mathrm{p}_{0}\right)$, dosis pupuk $100 \mathrm{~kg}$ NPK Pelangi setara 3,6 g/polibag $\left(\mathrm{p}_{1}\right)$, dan dosis pupuk $200 \mathrm{~kg}$ NPK Pelangi setara 7,2 g/polibag $\left(\mathrm{p}_{2}\right)$.

Hasil penelitian menunjukkan bahwa perlakuan pupuk kandang ayam tidak berpengaruh nyata terhadap tinggi tanaman umur 30 hari dan 45 hari setelah tanam, umur berbunga, umur panen, jumlah buah per tanaman dan berat buah per tanaman.

Perlakuan pupuk NPK Pelangi tidak berpengaruh nyata terhadap tinggi tanaman umur 30 hari dan 45 hari setelah tanam, umur berbunga, umur panen, jumlah buah per tanaman dan berat buah per tanaman.

Interaksi perlakuan pupuk kandang ayam dan pupuk NPK Pelangi tidak berpengaruh nyata terhadap tinggi tanaman umur 30 hari dan 45 hari setelah tanam, umur berbunga, umur panen, jumlah buah per tanaman dan berat buah per tanaman.
\end{abstract}

Kata kunci : Pupuk kandang ayam, Pupuk NPK, pertumbuhan, tomat.

\begin{abstract}
Effect of Chicken Manure and NPK Pelangi Fertilizer on the Growth and Results of Tomato Cherry Plant (Solanum Lycopersicum L.). The purpose of this research is to study the effect of chicken manure and NPK Pelangi fertilizer as well as its interaction on the growth and yield of cherry tomato plants, and also to find the proper dosage of chicken manure and NPK Pelangi fertilizer for maximum results .

The research was conducted for 4 months, starting from March to June 2017, from seeding to final data collection. It was carried out in Kampung Bentas RT 01, Siluq Ngurai Subdistrict, Kutai Barat Regency, East Kalimantan Province.

The research used a $3 \times 3$ factorial analysis in Completely Randomized Design (RAL), with 5 replications. The research factor consisted of 2 factors. Factor I was chicken manure dosage (K), consisting of 3 levels, that is : no chicken manure application or control $\left(\mathrm{k}_{0}\right), 5$ tons/ha, equaled to $180 \mathrm{~g} / \mathrm{polybag}\left(\mathrm{k}_{1}\right)$, and 10 tons/ha, equaled to $360 \mathrm{~g} /$ polybag $\left(\mathrm{k}_{2}\right)$. Faktor II was the dosage of NPK Pelangi fertilizer (P), consisting of 3 levels, that is: no NPK Pelangi application or control $\left(\mathrm{p}_{0}\right), 100 \mathrm{~kg} / \mathrm{ha}$ equaled to $3,6 \mathrm{~g} / \mathrm{polybag}\left(\mathrm{p}_{1}\right)$, and 200 $\mathrm{kg} /$ ha equaled $7,2 \mathrm{~g} /$ polybag $\left(\mathrm{p}_{2}\right)$.
\end{abstract}


The results showed that chicken manure treatment had no significant effect on the plant height at ages 30 days and 45 days after planting, age of plant flowered, age of plant harvested, number of fruit per plant, and fruit weight per palnt. NPK Pelangi fertilizer treatment did not affect significantly on the plant height at ages 30 days and 45 days after planting, age of plant flowered, age of plant harvested, number of fruit per plant and fruit weight per plant. Interaction treatmen of chicken manure and NPK Pelangi fertilizer had no significant effect on the plant height at ages 30 days and 45 days after planting, age of plant flowered, age of plant harvested, number of fruit per plant and fruit weight per plant.

Key words : Chicken Manure, NPK, Growth, Tomato.

\section{PENDAHULUAN}

Tomat (Solanum lycopersicum L.) Adalah salah satu jenis sayuran yang banyak digemari orang karena rasanya enak, segar, dan sedikit asam. Secara umum, tomat memiliki kandungan gizi dan vitamin, diantaranya kalori, protein, lemak, karbohidrat, kalsium, vitamin A, vitamin $\mathrm{C}$, dan sedikit vitamin $\mathrm{B}$. Tomat merupakan salah satu hasil pertanian yang nilai ekonominya cukup tinggi. Tanaman yang nilai ekonominya tinggi, biasanya memiliki risiko kegagalan dalam pemeliharaan yang tinggi pula. Pada tanaman tomat, beberapa hama patogen, gangguan iklim, dan pemeliharaan yang tidak benar dapat menyebabkan gagal panen. pada saat ini masalah yang sering dihadapi dalam pemeliharaan tomat adalah menurunnya mutu tomat. Hal ini disebabkan oleh seleksi benih yang kurang baik, teknik pemeliharaan yang belum sepenuhnya diterapkan, serta pengetahuan petani tomat yang masih kurang. kualitas produksi tomat yang baik sangat bergantung pada cara pengolahan tanah dan benih tanaman yang baik, karena tanaman tomat membutuhkan perawatan secara khusus dan ketelatenan yang ekstra. Di Indonesia.tomat banyak ditanam di daerah Jawa, Sumatra, dan daerah lainnya, selain untuk keperluan rumah tangga,tomat dapat digunakan untuk keperluan Industri, seperti Industri bumbu masakan, makanan, dan obatobatan (Prashasta, 2009)

Tomat merupakan satu dari sekian banyak jenis sayuran yang telah dikenal masyarakat. Menurut Andrew F.Smith dalam "The Tomato in America", tomat kemungkinan berasal dari dataran tinggi pantai barat Amerika Selatan. Setelah Spanyol menguasai Amerika Selatan, mereka menyebarkan tanaman tersebut ke koloni-koloni mereka di Karibia. Selain itu,Filipina juga menjadi titik awal penyebaran tomat didaerah lainnya diseluruh benua Asia. Spanyol juga membawa tomat ke Eropa. Tanaman ini tumbuh dengan mudah pada wilayah yang beriklim mediterania. Tomat kaya akan vitamin c yang berguna untuk meningkatkan kekebalan tubuh serta berbagai macam penyakit, seperti sariawan. Vitamin A yang berguna untuk mencegah dan mengobati xoeropthalmia pada mata juga banyak terkandung terkandung dalam tomat. sebagai sumber mineral, tomat mengandung Fe (zat besi) yang berguna untuk pembentukan sel darah merah atau hemoglobin (Supriati dan Siregar, 2015)

Luas panen dan produksi tanaman tomat di Kabupaten Kutai Barat tahun 2013 adalah 28 (ha) produksi 497 ton produktivitas 0,06 ton/ha (Anonim, 2013).

Salah satu cara untuk meningkatkan produksi tanaman tomat adalah dengan cara pemupukan. selain pupuk kompos, pupuk yang baik adalah pupuk kandang. salah satu pupuk kandang seperti pupuk dari kotoran ayam proses pembuatannnya sama seperti pupuk kompos. dikubur dahulu agar tidak berbau,dan dibiarkan mikrooorganisme yang mengurainya (Prashasta,2009). 
Pupuk Kandang hampir sama dengan kompos. Perbedaannya terletak pada bahan yang digunakan untuk fermentasi,yaitu dari kotoran hewan, salah satunya kotoran ayam. kandungan unsur haranya yang lengkap seperti natrium $(\mathrm{N})$, fosfor $(\mathrm{P})$, dan kalium $(\mathrm{K})$ membuat pupuk kandang cocok untuk dijadikan media tanam. Sebaiknya pupuk kandang yang akan digunakan sebagai media tanam dipilih yang sudah matang dan steril. kematangan pupuk kadang dicirikan dengan warnanya yang hitam kecoklatan. Kematangan pada pupuk ini terkait dengan pencegahan munculnya bakteri atau cendawan yang dapat merusak tanaman (Supriati dan Siregar, 2015).

Selain pupuk kandang yang digunakan untuk pemupukan tomat pupuk anorganik salah satunya Pupuk NPK Pelangi. Pupuk NPK Pelangi adalah salah satu jenis pupuk organik yang mengandung beberapa unsur hara yang dibutuhkan tanaman seperti $\mathrm{N}, \mathrm{P}$, dan $\mathrm{K}$ (pupuk majemuk) dengan kadar tinggi. Pupuk ini dibuat dengan pencampuran fisik 3 bahan baku berkualitas yang antara lain urea granul, diamonium phospat granul (DAP) dan KCI flake. Pupuk NPK pelangi berbentuk butiran (granul) berwarna warni. Keunggulan NPK pelangi salah satunya adalah adanya kandungan beberapa unsur hara mikro yang terdapat dalam pupuk NPK Pelangi seperti Boron, Sulfur, dan Magnesium (Mulyani Sutedjo, 2008).

Penelitian Pengaruh Pupuk NPK Pelangi (15:15:15) terhadap tanaman tomat pernah dilaksanakan pada Januari 2013 sampai bulan Mei 2013 di Kelurahan Melak Ilir RT.3 Kecamatan Melak, Kabupaten Kutai Barat. Hasil penelitian menunjukkan pupuk NPK Pelangi berpengaruh sangat nyata terhadap tinggi tanaman pada umur 2, 4 dan 6 minggu setelah tanam menghasilkan tomat yang lebih tinggi dibandingkan dengan perlakuan tanpa pupuk NPK Pelangi. Hasil rekapitulasi menunjukkan bahwa pemberian pupuk NPK Pelangi sebesar $250 \mathrm{~kg}$ ha- ${ }^{1}$ atau 2,50 g polibag- ${ }^{1}$ menghasilkan berat buah per tanaman yang paling tinggi, yaitu 218,33 $\mathrm{g} \mathrm{tanaman}^{-1}$, dan yang paling rendah pada perlakuan tanpa pupuk NPK Pelangi yaitu $120,82 \mathrm{~g}$ tanaman $^{-1}$ (Saberan dkk., 2014).

Budidaya tanaman tomat Cherry masih jarang dibudidayakan oleh masyarakat petani khususnya di Desa Bentas, Kecamatan Siluq Ngurai, Kabupaten Kutai Barat, terutama dalam media polibag. Berdasarkan uraian diatas maka dilakukan penelitian dengan judul “ Pengaruh Pupuk Kandang Ayam dan Pupuk NPK Pelangi Terhadap Pertumbuhan dan Hasil Tanaman Tomat Cherry (Solanum Lycopersicum L.). Tujuan Penelitian adalah: Mengetahui pengaruh pemberian pupuk kandang ayam dan NPK Pelangi beserta interaksinya terhadap pertumbuhan dan produksi tanaman tomat Cherry. Mengetahui dosis yang terbaik dari pupuk kandang ayam dan NPK pelangi untuk tanaman tomat Cherry.

\section{METODA PENELITIAN}

\subsection{Tempat dan Waktu}

Penelitian dilaksanakan di Kampung Bentas RT 01, Kecamatan Siluq Ngurai, Kabupaten Kutai Barat, Provinsi Kalimantan Timur. Pada bulan Maret-Juni 2017.

\subsection{Bahan dan Alat}

Bahan yang digunakan adalah benih tanaman tomat cherry, media tanam berupa tanah top soil, pupuk kandang ayam, dan Pupuk NPK Pelangi. Sedang peralatan yang digunakan adalah: cangkul untuk mengolah dan menggemburkan tanah, polibag besar ukuran $20 \mathrm{~cm} \quad x \quad 30 \mathrm{~cm}$, alat penyiraman (gembor), label untuk 
menandai tanaman, penggaris atau meteran, timbangan analitik, alat tulis, dan kamera untuk dokumentasi penelitian.

\subsection{Rancangan Percobaan}

Penelitian ini menggunakan percobaan faktoral 3 x 3 dengan Rancangan Acak Lengkap (RAL), yang terdiri dari dua faktor perlakuan dan lima ulangan :

Faktor pertama adalah Dosis Pupuk Kandang Ayam $(\mathrm{K})$ yang terdiri dari tiga taraf perlakuan, yaitu : $\mathrm{k}_{0}=$ tanpa pupuk kandang ayam (kontrol)

$\mathrm{k}_{1}=$ dosis pupuk kandang ayam 5 ton/ha setara $180 \mathrm{~g} /$ polibag $\mathrm{k}_{2}=$ dosis pupuk kandang ayam 10 ton/ha setara dengan $360 \mathrm{~g} /$ polibag Faktor kedua adalah Pupuk NPK Pelangi $(\mathrm{P})$ yang terdiri dari tiga taraf perlakuan, yaitu :

$\mathrm{p}_{0}=$ tanpa Pupuk NPK Pelangi (Kontrol)

$\mathrm{p}_{1}=$ dosis pupuk NPK Pelangi 100

$\mathrm{kg} / \mathrm{ha}$ setara 3,6 g/polibag

$\mathrm{p}_{2}=$ dosis pupuk NPK Pelangi 200 $\mathrm{kg} /$ ha setara $7,2 \mathrm{~g} /$ polibag.

\subsection{Pelaksanaan Penelitian}

\subsubsection{Persiapan media tanam dalam} polibag

Media yang digunakan dalam penelitian ini adalah tanah top soil yang diambil di sekitar tempat penelitian. Media tanah top soil kemudian dibersihkan dari semua kotoran seperti akar, batu, ranting, setelah itu dikering anginkan. Kemudian dimasukkan ke dalam polibag dengan berat tanah $5 \mathrm{~kg}$, sebanyak 45 polibag, dan disiapkan untuk cadangan sebanyak 9 polibag. kemudian polibag disusun secara acak sederhana dan diberi label sesuai perlakuan, dengan jarak antar polibag $60 \mathrm{~cm}$ x $60 \mathrm{~cm}$. Kemudian diberi pupuk kandang ayam sesuai dosis perlakuan, yaitu : tanpa pupuk kandang ayam atau kontrol $\left(\mathrm{k}_{0}\right)$, dosis pupuk kandang ayam 5 ton/ha setara $180 \mathrm{gr} /$ polibag $\left(\mathrm{k}_{1}\right)$, dan dosis pupuk kandang ayam 10 ton/ha setara 360 gr/polibag, diberikan satu minggu sebelum tanam, dengan cara dicampur dengan media tanah dalam polibag, kemudian diaduk supaya merata keseluruh media tanam.

\subsubsection{Penyemaian dan seleksi benih}

Benih tomat yang ditanam adalah benih yang disiapkan sendiri.buah tomat dibelah secara memanjang dari pangkal sampai ujung tomat, buah tomat yang telah dibelah dikeluarkan bijinya, lalu dikering-anginkan. Benih direndam dulu dalam air hangat, dan dibiarkan selama 10-15 menit, sambil menyeleksi benih yang kurang baik. Benih yang tenggelam diambil untuk bibit, dan tujuan perendaman adalah agar benih cepat tumbuh. Penyemaian bibit. bibit tomat cherry dilakukan dalam media campuran topsoil dan pupuk kandang ayam. Media semai diletakkan dalam polibag semai. Dibuat lubang pada media semai dengan kedalaman $1 \mathrm{~cm}$, kemudian letakkan biji lalu tutup lagi dengan tanah. Basahi media semai secukupnya (tomat tidak menyukai genangan air).

\subsubsection{Penanaman bibit di media} tanam polibag

Bibit tomat cherry yang telah berdaun 2-3 helai atau berumur 2 minggu telah dapat dipindah ke dalam polibag. Pertama, bibit dipindahkan dengan cara dicabut. Caranya siram persemaian dengan air agar media tanam menjadi lunak. lalu mencabut tanaman dengan hati-hati agar akar tanaman tidak putus atau rusak. Kedua bibit tersebut dimasukkan 
secara tegak lurus pada lubang tanam yang ada dalam polibag ukuran $20 \mathrm{x}$ $30 \mathrm{~cm}$ pada sore hari, dan tiap polibag ditanam 1 bibit tomat. Posisi akar harus tegak lurus jangan sampai bengkok atau terlipat. Atur kedalaman lubang tanam sesuai dengan panjang akar.

\subsubsection{Pemberian pupuk NPK Pelangi} Pupuk NPK Pelangi diberikan sehari setelah tanam, dengan cara ditaburkan di sekeliling tanaman tomat, kemudian ditutup dengan tanah, pemberian pupuk sesuai dengan dosis perlakuan, yaitu : tanpa pupuk NPK Pelangi atau kontrol $\left(\mathrm{p}_{0}\right)$, dosis pupuk NPK Pelangi $100 \mathrm{~kg} / \mathrm{ha}$ setara 3,6 g/polibag $\left(\mathrm{p}_{1}\right)$, dan dosis pupuk NPK Pelangi $200 \mathrm{~kg} / \mathrm{ha}$ setara 7,2 $\mathrm{g} /$ polybag $\left(\mathrm{p}_{2}\right)$.

\subsubsection{Pemeliharaan}

Pemeliharaan yang dilakukan yaitu penyulaman. Penyiraman, penyiangan, pemasanngan ajir, perempelan, pengendalian hama dan penyakit, waktu panen pada saat umur 70-90 hari.

\subsection{Pengamatan dan Pengambilan Data}

Data yang diambil atau dikumpulkan dalam penelitian ini adalah sebagai berikut :

Tinggi Tanaman $(\mathrm{cm})$

Tinggi tanaman diukur pada umur 30 dan 45 hari setelah tanam, diukur dari pangkal batang di atas permukaan tanah (diberi tanda) hingga ujung tanaman (tunas paling ujung), dengan menggunakan meteran.

Umur berbunga (hari)

Dengan menghitung jumlah hari mulai bibit tanaman dipindahkan ke polibag hingga saat pertama kali berbunga.

Umur Panen (hari)
Dengan menghitung jumlah hari mulai bibit tanaman dipindahkan ke polibag hingga saat panen pertama. Jumlah buah per tanaman (buah) Jumlah buah per tanaman dihitung dengan cara menjumlahkan banyak buah dalam satu tanaman, sebanyak lima (5) kali panen.

Berat buah per tanaman $(\mathrm{g})$

Berat buah per tanaman dihitung dengan cara menjumlahkan berat buah tiap kali panen per tanaman, sebanyak lima (5) kali panen.

\subsection{Analisis Data}

Untuk mengetahui pengaruh perlakuan pupuk kandang ayam dan pupuk NPK Pelangi serta interaksinya terhadap pertumbuhan dan hasil tanaman tomat cherry. maka dilakukan dengan menganalisis data hasil pengamatan dengan sidik ragam. Adapun model sidik ragam yang digunakan menurut Yitnosumarto (1993). Bila hasil sidik ragam terhadap perlakuan berbeda tidak nyata (non signifikan) yang menunjukan $\mathrm{F}$ hitung $\leq \mathrm{F}$ tabel 0,05 , maka tidak dilakukan uji lanjutan, tetapi bila hasil sidik ragam terhadap perlakuan berbeda nyata (signifikan) yang menunjukan $\mathrm{F}$ hitung $\geq \mathrm{F}$ tabel 0,05 , atau berbeda sangat nyata yang menunjukkan $\mathrm{F}$ hitung $\geq \mathrm{F}$ tabel 0,01 , maka untuk membandingkan dua rata-rata perlakuan, dilakukan dengan uji Beda Nyata Terkecil (BNT) Taraf $5 \%$.

Rumus Umum Uji BNT disajikan sebagai berikut :

BNT 5\% -T-TABEL (a,db) x $\sqrt{2 \text { KT galat } / r}$

\footnotetext{
Keterangan :

$\mathrm{t}$-tabel = nilai $\mathrm{t}$-tabel $($ sebaran nilaipada $\mathrm{t}-$ student a $5 \%$ dengan dbnya)

KT galat $=$ kuadrat tengah galat

$\mathrm{r} \quad=$ jumlah ulangan
} 


\section{HASIL PENELITIAN DAN PEMBAHASAN}

\subsection{Tinggi Tanaman $(\mathrm{cm})$}

Tinggi Tanaman Umur 30 Hari Setelah Tanam

Hasil sidik ragam menunjukkan bahwa perlakuan pupuk kandang ayam (K) dan pupuk NPK Pelangi (P) serta interaksinya $(\mathrm{KxP})$ tidak berpengaruh nyata terhadap tinggi tanaman umur 30 hari setelah tanam Tabel 1.

Tinggi Tanaman Umur 45 Hari Setelah Tanam

Hasil sidik ragam menunjukkan bahwa perlakuan pupuk kandang ayam (K) dan pupuk NPK Pelangi (P) serta interaksinya $(\mathrm{KxP})$ tidak berpengaruh nyata terhadap tinggi tanaman umur 45 hari setelah tanam Tabel 1

\subsection{Umur Berbunga (hari)}

Hasil sidik ragam menunjukkan bahwa perlakuan pupuk kandang ayam (K) dan pupuk NPK Pelangi (P) serta interaksinya $(\mathrm{KxP})$ tidak berpengaruh nyata terhadap umur berbunga Tabel 1 .

\subsection{Umur Panen (hari)}

Hasil sidik ragam menunjukkan bahwa perlakuan pupuk kandang ayam (K) dan pupuk NPK Pelangi (P) serta interaksinya $(\mathrm{KxP})$ tidak berpengaruh nyata terhadap umur panen Tabel 1 .

\subsection{Jumlah Buah Per Tanaman (buah)}

Hasil sidik ragam menunjukkan bahwa perlakuan pupuk kandang ayam (K) dan pupuk NPK Pelangi (P) serta interaksinya $(\mathrm{KxP})$ tidak berpengaruh nyata terhadap jumlah buah per tanaman Tebel 1.

\subsection{Berat Buah Per Tanaman (g)}

Hasil sidik ragam menunjukkan bahwa perlakuan pupuk kandang ayam (K) dan pupuk NPK Pelangi (P) serta interaksinya $(\mathrm{KxP})$ tidak berpengaruh nyata terhadap berat buah per tanaman Tabel 1.

Tabel 1. Rekapitulasi Data Penelitian Pengaruh Pupuk Kandang Ayam dan Pupuk NPK Pelangi Terhadap Perumbuthan dan Hasil Tanaman Tomat Cherry (Solanum lycopersicum L.)

\begin{tabular}{|c|c|c|c|c|c|c|}
\hline \multirow[b]{2}{*}{ Faktor Perlakuan } & \multicolumn{2}{|c|}{ Tinggi Tanaman $(\mathrm{cm})$} & \multirow{2}{*}{$\begin{array}{c}\text { Umur } \\
\text { Berbunga } \\
\text { (hari) }\end{array}$} & \multirow{2}{*}{$\begin{array}{c}\text { Umur } \\
\text { Panen (hari) }\end{array}$} & \multirow{2}{*}{$\begin{array}{c}\text { Jumlah } \\
\text { Buah/ } \\
\text { Tanaman } \\
\text { (buah) }\end{array}$} & \multirow{2}{*}{$\begin{array}{l}\text { Berat Buah/ } \\
\text { Tanaman }(\mathrm{g})\end{array}$} \\
\hline & $30 \mathrm{HST}$ & $45 \mathrm{HST}$ & & & & \\
\hline \multicolumn{7}{|l|}{$\begin{array}{l}\text { Pupuk Kandang } \\
\text { Ayam }(\mathrm{K})\end{array}$} \\
\hline Sidik Ragam & tn & tn & tn & tn & tn & tn \\
\hline 20 ton/ha $\left(\mathrm{k}_{2}\right)$ & 35,20 & 42,60 & 36,40 & 61,20 & 51,07 & 188,73 \\
\hline \multicolumn{7}{|l|}{$\begin{array}{l}\text { Pupuk NPK Pelangi } \\
\text { (P) }\end{array}$} \\
\hline Sidik Ragam & tn & tn & tn & tn & tn & $\operatorname{tn}$ \\
\hline Sidik Ragam & tn & $\operatorname{tn}$ & $\operatorname{tn}$ & $\operatorname{tn}$ & $\operatorname{tn}$ & tn \\
\hline $\mathrm{k}_{0} \mathrm{p}_{0}$ & 29,80 & 40,60 & 40,00 & 61,20 & 46,00 & 142,80 \\
\hline $\mathrm{k}_{0} \mathrm{p}_{1}$ & 31,40 & 37,20 & 40,00 & 61,20 & 41,40 & 173,40 \\
\hline $\mathrm{k}_{0} \mathrm{p}_{2}$ & 33,80 & 43,00 & 38,00 & 61,20 & 53,00 & 170,60 \\
\hline $\mathrm{k}_{1} \mathrm{p}_{0}$ & 31,40 & 39,80 & 37,20 & 61,60 & 46,40 & 180,80 \\
\hline $\mathrm{k}_{1} \mathrm{p}_{1}$ & 32,60 & 41,80 & 36,00 & 61,60 & 47,20 & 149,20 \\
\hline $\mathrm{k}_{1} \mathrm{p}_{2}$ & 34,40 & 42,40 & 39,20 & 61,40 & 47,00 & 194,20 \\
\hline
\end{tabular}




\begin{tabular}{lllllll}
$\mathrm{k}_{2} \mathrm{p}_{0}$ & 31,60 & 39,40 & 37,20 & 62,60 & 44,20 & 177,60 \\
$\mathrm{k}_{2} \mathrm{p}_{1}$ & 33,20 & 42,40 & 38,00 & 62,44 & 54,80 & 189,80 \\
$\mathrm{k}_{2} \mathrm{p}_{2}$ & 37,40 & 46,00 & 34,00 & 62,60 & 54,20 & 198,80 \\
\hline
\end{tabular}

Keterangan :

* : berpengaruh nyata

** : berpengaruh sangat nyata

tn : tidak berpengaruh nyata

HST : Hari Setelah Tanam

$\mathrm{p}_{0}$ : tanpa pupuk NPK Pelangi (kontrol)

$\mathrm{p}_{1}$ : dosis pupuk NPK Pelangi $100 \mathrm{~kg} / \mathrm{ha}$

$\mathrm{p}_{1}$ : dosis pupuk NPK Pelangi $200 \mathrm{~kg} / \mathrm{ha}$

$\mathrm{k}_{0}$ : tanpa pupuk kandang ayam (kontrol)

$\mathrm{k}_{1}$ : dosis pupuk kandang ayam 10 ton/ha

$\mathrm{k}_{1}$ : dosis pupuk kandang ayam 20 ton/ha

Hasil sidik ragam pada perlakuan pupuk kandang ayam tidak berpengaruh nyata terhadap tinggi tanaman umur 30 hari dan 45 hari setelah tanam, umur berbunga, umur panen, jumlah buah per tanaman dan berat buah per tanaman Tabel 1.

Tidak adanya pengaruh yang nyata pada perlakuan pupuk kandang ayam diduga bahwa selain kandungan unsur hara pada pupuk kandang ayam rendah, juga disebabkan $\mathrm{pH}$ tanah yang sangat asam ( $\mathrm{pH} 3,52$ ), juga kejenuhan basa sangat rendah $(13,10)$ seperti terlihat pada Tabel 1 , sehingga unsur hara yang diberikan terjerab pada koloid tanah liat dan bahan organik, sehingga sukar larut dan tidak tersedia bagi tanaman, sehingga tanaman kekurangan nutrisi untuk pertumbuhan vegetatif dan generatif, seperti tinggi, umur berbunga, umur panen, jumlah buah per tanaman dan berat buah per tanaman. Hal ini sesuai dengan pendapat Winarso (2005), bahwa pada tanah asam, kelarutan unsur $\mathrm{Al}, \mathrm{Fe}$ dan $\mathrm{Mn}$ sangat tinggi, sehingga bisa meracuni akar tanaman. Selain itu juga dengan pemberian bahan organik, seperti pupuk kandang akan memperbaiki sifat fisik tanah untuk jangka panjang tetapi kurang efektif untuk peningkatan unsur hara didalam tanah. Hasil Penelitian analisa tanah di Desa Giri Agung KTK kebanyakan rendah, dan masam adapun KTK yang rendah dapat ditingkatkan dengan penggunaan pupuk organik yang berguna untuk meningkatkan tanah menjadi gembur dan daya jerap tanah dan untuk meningkatkan kapasitas tukar kation sehingga dapat menampung apabila dilakukan penambahan unsur hara baik secara alami maupun dengan penambahan pupuk (Datu BP et al. 2013). Selanjutnya pemupukan ditentukan oleh keadaan tanah seperti Tanah-tanah pada lokasi studi menunjukkan reaksi tanah agak masam perlu dilakukan pemberian kapur (I Gede EB et al.2017).

Pengaruh Pupuk NPK Pelangi Terhadap Tanaman Tomat Cherry (Solanum lycopersicum L.). Hasil sidik ragam pada perlakuan pupuk NPK Pelangi tidak berpengaruh nyata terhadap tinggi tanaman umur 30 hari dan 45 hari setelah tanam, umur berbunga, umur panen, jumlah buah per tanaman dan berat buah per tanaman Tabel 1 .

Secara statistik perlakuan pupuk NPK Pelangi tidak berpengaruh nyata terhadap semua parameter yang diamati, walaupun dosis pupuk yang diberikan cukup tinggi, yaitu $100 \mathrm{~kg} / \mathrm{ha}$ dan 200 $\mathrm{kg} / \mathrm{ha}$. Tetapi bila dikonversi untuk tiap tanaman, maka jumlahnya menjadi sedikit, yaitu sekitar 3,6 g/tanaman untuk dosis $100 \mathrm{~kg} / \mathrm{ha}$ dan 7,2 g/tanaman untuk dosis $200 \mathrm{~kg} / \mathrm{ha}$. Ditambah lagi dengan keadaan media tanah dalam polibag yang tingkat keasamannya sangat rendah $(\mathrm{pH}$ 3,52 ), maka pemberiannya menjadi tidak efektif, karena tidak dapat serap oleh akar tanaman, karena terikat oleh koloid liat dan koloid humus (bahan organik) didalam tanah, hal ini sesuai dengan pendapat Hardjowigeno (2010). 
Pengaruh Interaksi Perlakuan Pupuk Kandang Ayam dan Pupuk NPK Pelangi Terhadap Tanaman Tomat Cherry (Solanum lycopersicum L.). Hasil sidik ragam pada interaksi perlakuan pupuk kandang ayam dan pupuk NPK Pelangi tidak berpengaruh nyata terhadap tinggi tanaman umur 30 hari dan 45 hari setelah tanam, umur berbunga, umur panen, jumlah buah per tanaman dan berat buah per tanaman Tabel 1 .

Interaksi perlakuan pupuk kandang ayam dan pupuk NPK Pelangi pada parameter penelitian tidak menunjukkan hasil yang nyata, karena baik faktor perlakuan pupuk kandang ayam maupun faktor pupuk NPK Pelangi juga tidak menunjukkan hasil yang nyata pada semua parameter yang diamati.

\section{KESIMPULAN}

Berdasarkan hasil penelitian dapat disimpulkan : 1) Perlakuan pupuk kandang ayam tidak berpengaruh nyata terhadap tinggi tanaman umur 30 hari dan 45 hari setelah tanam, umur berbunga, umur panen, jumlah buah per tanaman dan berat buah per tanaman. 2) Perlakuan pupuk NPK Pelangi tidak berpengaruh nyata terhadap tinggi tanaman umur 30 hari dan 45 hari setelah tanam, umur berbunga, umur panen, jumlah buah per tanaman dan berat buah per tanaman. 3) Interaksi perlakuan pupuk kandang ayam dan pupuk NPK Pelangi tidak berpengaruh nyata terhadap tinggi tanaman umur 30 hari dan 45 hari setelah tanam, umur berbunga, umur panen, jumlah buah per tanaman dan berat buah per tanaman.

\section{DAFTAR PUSTAKA}

Anonim. 2013. Kutai Barat Dalam Angka 2013. Badan Pusat Statistik Kabupaten Kutai Barat.
EB, I. Gede, and Maya PB Jumani. "Evaluation of Soil Revegetation Success Rate Ex-Pit Coal Mine in Kitadin site Embalut Kutai in East Kalimantan." Agrifor 16.2 (2017): 195-208.

Hardjowigeno, S. 2010. Ilmu Tanah. Akademika Pressindo. Jakarta.

Mulyani Sutedjo, M. 2008. Pupuk dan Cara Pemupukan. Rineka Cipta. Jakarta.

Pramana, Datu Bandar. "Pertumbuhan Tanaman Gaharu (Aquilaria sp.) di Desa Giri Agung Kecamatan Sebulu Kabupaten Kutai Kartanegara Provinsi Kalimantan Timur." AGRIFOR 11.2 (2013): 110-114.

Prashasta, A. 2009. Agibisnis Tomat hal 1-81.CV.
Grafika.Bandung Pustaka

Saberan, N., Rahmi, A, dan Syahfari, H. 2014 Pengaruh Pupuk NPK Pelangi Terhadap Pertumbuhan dan Hasil Tanaman Tomat. Jurnal AGRIFOR Volume XII, Nomor 1, Maret 2014.

Supriati, Y, dan Siregar, F.D 2015. Bertanam Tomat di Pot. Penebar Swadaya. Jakarta.

Winarso, S. 2005. Kesuburan Tanah, Dasar Kesehatan dan Kualitas Tanah. Gaya Media. Yogyakarta.

Yitnosumarto. 1993. Percobaan Perancangan, Analisis dan Interpretasinya. PT. Gramedia Pustaka Utama. Jakarta. 